\title{
Edoxaban for prevention of venous thromboembolism after major orthopedic surgery
}

\author{
Hiroyuki Kawaji' \\ Masaji Ishii \\ Yasunobu Tamaki' \\ Kan Sasaki ${ }^{2}$ \\ Michiaki Takagi \\ 'Department of Orthopaedic Surgery, \\ Saiseikai Yamagata Saisei Hospital, \\ ${ }^{2}$ Department of Orthopaedic Surgery, \\ Yamagata University Faculty of \\ Medicine, Yamagata, Japan
}

Correspondence: Hiroyuki Kawaji Department of Orthopaedic Surgery, Saiseikai Yamagata Saisei Hospital,

79-I Okimachi, Yamagata, Japan

$\mathrm{Tel}+8123682$ I I I I

Fax +81236820122

Email hiroyuki.kawaji@ameria.org
This article was published in the following Dove Press journal:

Orthopedic Research and Reviews

26 May 2012

Number of times this article has been viewed

\begin{abstract}
Fatal pulmonary thromboembolism is the most serious complication following surgery. Patients undergoing major orthopedic surgeries, including total hip replacement, total knee replacement, and hip fracture surgery, represent a group at particularly high risk of venous thromboembolism. Therefore, prophylaxis for thromboembolic events has been of great concern to surgeons. Edoxaban is a novel, orally available, and highly specific and direct factor $\mathrm{Xa}$ inhibitor. This new agent was approved for the prevention of venous thromboembolism in patients undergoing major orthopedic surgery, including total hip replacement, total knee replacement, and hip fracture surgery, by the Japanese Ministry of Health, Labor, and Welfare in 2011. Preclinical and Phase I clinical trials demonstrated several promising properties. Its rapid absorption and short life-time in blood are known. Edoxaban inhibits factor Xa activity directly and selectively. It also has a strong antithrombotic effect without any influence of food intake. Coagulation monitoring is not required. Edoxaban has predictable linear pharmacokinetic and pharmacodynamic profiles. Phase II and III clinical trials have been completed to examine its efficacy and safety in patients undergoing major orthopedic surgery. In these clinical trials, oral administration of edoxaban showed efficacy superior to that of oral placebo or subcutaneously administered dalteparin or enoxaparin. Edoxaban can be regarded as a first choice to prevent venous thromboembolism after major orthopedic surgery.
\end{abstract}

Keywords: edoxaban, thromboprophylaxis, venous thromboembolism, total hip replacement, total knee replacement, hip fracture surgery

\section{Introduction}

Venous thromboembolism, ie, deep vein thrombosis and pulmonary embolism, is an important cause of death in hospitalized patients, and treatment of nonfatal symptomatic venous thromboembolism and related long-term morbidities is associated with a considerable cost to the health care service. ${ }^{1}$ Venous thromboembolism is a potentially fatal disease. ${ }^{2,3}$ Patients undergoing major orthopedic surgery, which includes total hip replacement, total knee replacement, and hip fracture surgery, are a group at particularly high risk for venous thromboembolism ${ }^{4,5}$ and fatal pulmonary embolism, which is a catastrophic complication of major orthopedic surgery. ${ }^{6}$ Most pulmonary emboli are thought to develop from deep vein thromboses. ${ }^{5,7-9}$ The incidence of venous thromboembolism is $0.05 \%-0.2 \%$ in the general community. ${ }^{10-13}$ The incidence of total venographically detected deep vein thrombosis 7-14 days following total hip replacement, total knee replacement, and hip fracture surgery in prospective clinical trials in which patients received no thromboprophylaxis or placebo has been $42 \%-57 \%,{ }^{14-22} 41 \%-85 \%,{ }^{14,23-30}$ and $46 \%-60 \%,{ }^{14,31-33}$ respectively. The prevalence 
of fatal pulmonary embolism derived from prospective studies that may have used thromboprophylaxis is $0.1 \%$ $2.0 \%,{ }^{14,18,34-38} 0.1 \%-1.7 \%,{ }^{6,14,31,36,39,40}$ and $0.3 \%-7.5 \%{ }^{14,18,33,41}$ in patients undergoing total hip replacement, total knee replacement, and hip fracture surgery, respectively.

Pulmonary embolism is the most common preventable cause of hospital death and the number one strategy to improve patient safety in hospitals. ${ }^{4}$ Therefore, prophylaxis of deep vein thrombosis, especially proximal deep vein thrombosis, which has the potential to develop into pulmonary embolism, has been of great concern to surgeons. The worldwide clinical guidelines, including those from the American College of Chest Physicians, ${ }^{4}$ National Institute for Health and Clinical Excellence, ${ }^{1}$ and American Association of Orthopedic Surgeons, ${ }^{42}$ recommend mechanical and/or pharmacological thromboprophylaxis for the prevention of deep vein thrombosis in patients undergoing major orthopedic surgery. Those guidelines are summarized along with the differences between the recommendations, but all guidelines accept that the most important goal of thromboprophylaxis is to prevent fatal pulmonary embolism. ${ }^{43}$

Warfarin and unfractionated heparin have been used as standard anticoagulants for the prevention and treatment of embolism for over 50 years. ${ }^{4,44}$ Recently, the low molecular weight heparins or synthetic pentasaccharide, fondaparinux, which indirectly inhibits activated factor X (factor Xa), have been used for prevention of deep vein thrombosis after major orthopedic surgery. ${ }^{4,44,45,48,49}$ However, warfarin has numerous clinically important limitations, including slow onset and offset of action, narrow therapeutic windows, and a high degree of interindividual and intraindividual variation of response requiring routine coagulation monitoring, and multiple food-drug and drug-drug interactions. ${ }^{50-52}$ An objection to using chemical deep vein thrombosis prophylaxis is the increased risk of bleeding as a result of anticoagulation. The estimated baseline risk of major or significant bleeding in the absence of chemical deep vein thrombosis prophylaxis is $2 \%{ }^{1}$ The benefit of deep vein thrombosis prophylaxis has to be weighed against the risks and consequences of postoperative bleeding. The heparins are also associated with an increased risk of bleeding, ${ }^{53}$ as well as nonhemorrhagic side effects, such as heparin-induced thrombocytopenia ${ }^{49,54,55}$ and osteoporosis. ${ }^{49}$ Moreover, the response to fixed doses of unfractionated heparin is unpredictable because of binding to plasma proteins. ${ }^{53}$ Low molecular weight heparin preparations have more predictable pharmacokinetic and pharmacodynamic properties, a longer half-life than heparin in blood, and a lower risk of nonhemorrhagic side effects. Fondaparinux catalyzes inhibition of factor Xa. Heparin-induced thrombocytopenia and osteoporosis are unlikely to occur because fondaparinux binds only to antithrombin. Fondaparinux has a longer half-life than low molecular weight heparin. However, heparins and fondaparinux are only available for parenteral administration. ${ }^{49}$

Edoxaban tosylate hydrate (edoxaban, Lixiana ${ }^{\circledR}$, the free base of DU-176b, Daiichi Sankyo Co Ltd, Tokyo, Japan) is a novel, orally available, and highly specific and direct inhibitor of factor Xa. ${ }^{56,57}$ Factor Xa has a critical role in the coagulation cascade, because it is generated at the convergence point of the intrinsic and extrinsic coagulation pathways from direct activation of factor $\mathrm{X}$ by tissue factor. ${ }^{58}$ Therefore, factor $\mathrm{Xa}$ has been thought to represent a promising target for prophylaxis and treatment of thromboembolic diseases.

Edoxaban $15 \mathrm{mg}$ and $30 \mathrm{mg}$ tablets were approved for prevention of deep vein thrombosis in patients undergoing total hip replacement, total knee replacement, and hip fracture surgery by the Japanese Ministry of Health, Labor, and Welfare in April 2011 and launched in July 2011 in Japan. ${ }^{59}$ In this paper, we review the results of clinical trials carried out with edoxaban for prevention of deep vein thrombosis after major orthopedic surgery.

The present review includes: in vitro and/or in vivo studies performed prior to clinical studies, which were presented or published, including meeting abstracts; Phase I studies that have examined the clinical safety, tolerability, pharmacokinetics, and/or pharmacodynamics in healthy subjects; studies that have included patients undergoing major orthopedic surgery and evaluated the efficacy and safety of edoxaban for the prevention of deep vein thrombosis; and Phase II and III studies with a randomized design and control groups, providing a direct comparison between different dosages of edoxaban or between edoxaban and a comparator.

\section{Preclinical studies}

The potent anti-factor Xa activity and dose-dependent inhibition of thrombosis by edoxaban have been well characterized in nonclinical studies. In vitro, edoxaban demonstrated 10,000-fold selectivity relative to inhibition of thrombin. ${ }^{60}$ Inhibition of human factor Xa by edoxaban was concentration-dependent and competitive, with inhibition constant $(\mathrm{Ki})$ values of $0.561 \mathrm{nM} .^{57}$ In rats and rabbits, edoxaban exerted significant and dose-dependent anti-factor Xa activity in plasma. ${ }^{57,60}$ Edoxaban dose-dependently inhibited thrombus formation in vitro and in vivo. ${ }^{57,60,61}$ Prothrombin time was prolonged in a concentration-dependent 
and dose-dependent manner. ${ }^{57,60}$ Edoxaban also prolonged activated partial thromboplastin time and = prothrombin time in human plasma in a concentration-dependent manner. ${ }^{57,60}$ Edoxaban exhibited high oral bioavailability in rats and monkeys and antithrombotic effects in both venous and arterial models of thrombosis in rats. ${ }^{60}$ There was significant factor Xa inhibition activity in rat plasma 30 minutes after oral administration of edoxaban, indicating a fast onset of action. ${ }^{57,61}$ In monkeys, edoxaban also elicited rapid onset of antifactor Xa activity, reaching a peak at 4 hours and persisting for 24 hours after dosing. ${ }^{57}$ Comparisons of the antithrombotic and hemorrhagic effects of edoxaban with those of dalteparin (low molecular weight heparin), unfractionated heparin, and warfarin in rat models indicated that the therapeutic dose range of edoxaban would be wider than that of other anticoagulants. ${ }^{61}$ These results demonstrate that edoxaban is a potent and highly selective direct factor Xa inhibitor and might be a promising oral anticoagulant for the prophylaxis and treatment of thromboembolic disease.

\section{Phase I studies}

In a Phase I study, the effect of a single $60 \mathrm{mg}$ dose of edoxaban on ex vivo thrombus formation and on factor $\mathrm{Xa}$ activity was examined in young healthy subjects. ${ }^{56}$ Peak plasma levels of edoxaban were observed at 1.5 hours after oral administration, corresponding to maximum anti-factor Xa activity, which came down at 5 hours and returned to baseline levels after 12 hours. The greatest antithrombotic effect was similarly observed at 1.5 hours, while the effect was significant even at 5 hours. Edoxaban demonstrated strong antithrombotic properties. Inhibition of factor Xa led to a corresponding reduction in generation of thrombin. Edoxaban demonstrated a strong antithrombotic effect, with rapid onset of action and a short-life.

Another Phase I study examined the clinical safety, tolerability, pharmacokinetics, and pharmacodynamics of ascending single and multiple oral doses of edoxaban in healthy male volunteers. ${ }^{62}$ Edoxaban was rapidly absorbed, with a peak drug concentration time of 1-2 hours and a halflife ranging from 5.8 to 10.7 hours. Low intersubject and intrasubject variability of plasma edoxaban concentrations was observed. Single-dose administration of edoxaban exhibited dose-dependent effects on activated partial thromboplastin time, prothrombin time, international normalized ratio, and anti-factor Xa activity. There were no clinically significant effects of food on the pharmacokinetics and pharmacodynamics. ${ }^{63}$ Edoxaban was safe and well tolerated in single doses up to $150 \mathrm{mg}$ and multiple doses up to $120 \mathrm{mg} /$ day for 10 days, with no dose-dependent increase in drug-related adverse events. Edoxaban appears to have predictable and consistent pharmacokinetic and pharmacodynamic profiles across doses, with low intersubject variability and dose linearity. The predictable pharmacokinetic and pharmacodynamic profiles of edoxaban, lack of a food effect, and low plasma protein binding suggest that coagulation monitoring might not be required for this agent. In another study which enrolled healthy elderly volunteers, oral administration of edoxaban resulted in effective inhibition of factor Xa and thrombin generation, and was well tolerated. ${ }^{64}$ There were no serious adverse events. These characteristics suggested that edoxaban might provide consistent anticoagulation for a wide range of patients.

\section{Phase Ila study of blood clot prevention in total hip replacement}

Based on the wealth of available preclinical data and promising results of Phase I studies, a multicenter, multinational, openlabel, dose-ranging Phase IIa study of the efficacy, safety, and tolerability of oral edoxaban administered once or twice daily was initiated in adult patients undergoing total hip replacement (NCT00107900 http://www.clinicaltrials.gov). ${ }^{65}$ This trial enrolled approximately 600 patients to receive once or twice daily oral doses of edoxaban. The trial was reportedly completed in July 2005, but no data are currently available. ${ }^{65,66}$

\section{Phase Ilb study of venous thromboembolism prevention in total hip replacement}

A randomized, parallel-group, double-blind, double-dummy, multicenter, multinational, multidose Phase IIb study assessed the clinical utility of edoxaban for prevention of deep vein thrombosis compared with dalteparin, a low molecular weight heparin, in patients undergoing elective total hip replacement (NCT00398216 http://www.clinicaltri als.gov, Table 1). ${ }^{67}$ The doses of edoxaban evaluated were 15 , 30,60 , and $90 \mathrm{mg}$ given orally once daily. The comparator regimen of subcutaneous dalteparin involved an initial dose of $2500 \mathrm{IU}$ followed by $5000 \mathrm{IU}$ once daily thereafter. Both the oral and subcutaneous study medications were started 6-8 hours postoperatively and continued for 7-10 days postoperatively, at which time patients were evaluated at an end of treatment visit. Deep vein thrombosis was examined by bilateral venography at $7-10$ days postoperatively and within 24 hours of the last dose of study medication. A total of 903 patients were enrolled. Patients were recruited 
Table I Summary of clinical trials of edoxaban in development for the prevention of deep vein thrombosis after major orthopedic surgery

\begin{tabular}{|c|c|c|c|c|}
\hline $\begin{array}{l}\text { Indication } \\
\text { phase/trial } \\
\text { (government identifier) }\end{array}$ & Design & Location & $\begin{array}{l}\text { Treatment } \\
\text { (Edoxaban versus comparator) }\end{array}$ & $\begin{array}{l}\text { Patient } \\
\text { number }\end{array}$ \\
\hline \multicolumn{5}{|l|}{ THR } \\
\hline $\begin{array}{l}\text { Phase Ilb/nameless } \\
(\text { NCT0003982 I6) }\end{array}$ & $\begin{array}{l}\text { Randomized, parallel-group, } \\
\text { double-blind, double-dummy, } \\
\text { dalteparin-controlled, } \\
\text { multidose, multicenter, } \\
\text { multinational }\end{array}$ & $\begin{array}{l}\text { US, Canada, } \\
\text { Russia, Ukraine, } \\
\text { Denmark, Latvia, UK }\end{array}$ & $\begin{array}{l}\text { Edoxaban } 15,30,60,90 \mathrm{mg} \text { once daily } \\
\text { versus dalteparin initial dose of } 2500 \mathrm{IU} \\
\text { followed by } 5000 \mathrm{IU} \text { once daily for } \\
7-10 \text { days }\end{array}$ & 903 \\
\hline $\begin{array}{l}\text { Phase Ilb/STARS J-2 } \\
\left(^{\text {NCTOI 203098) }}{ }^{69}\right.\end{array}$ & $\begin{array}{l}\text { Randomized, parallel-group, } \\
\text { double-blind, open-label, } \\
\text { enoxaparin-controlled, } \\
\text { multidose, multicenter }\end{array}$ & $\begin{array}{l}\text { Japan, } \\
\text { Taiwan }\end{array}$ & $\begin{array}{l}\text { Edoxaban } 15,30 \mathrm{mg} \text { once daily versus } \\
\text { enoxaparin } 20 \mathrm{mg} \text { twice daily for } \\
\text { II-14 days }\end{array}$ & 264 \\
\hline $\begin{array}{l}\text { Phase III/STARS J-5 } \\
(\text { NCT0I I } 8 \text { I I67) }\end{array}$ & $\begin{array}{l}\text { Randomized, parallel-group, } \\
\text { double-blind, double-dummy, } \\
\text { enoxaparin-controlled, } \\
\text { noninferiority, multicenter }\end{array}$ & Japan & $\begin{array}{l}\text { Edoxaban } 30 \mathrm{mg} \text { once daily versus } \\
\text { enoxaparin } 20 \mathrm{mg} \text { twice daily for } \\
\text { II-I4 days }\end{array}$ & 610 \\
\hline \multicolumn{5}{|l|}{ TKR } \\
\hline $\begin{array}{l}\text { Phase Ilb/STARS J-I } \\
(\text { NCT0I 203072) })^{68}\end{array}$ & $\begin{array}{l}\text { Randomized, parallel-group, } \\
\text { double-blind, placebo- } \\
\text { controlled, dose-ranging, } \\
\text { multicenter }\end{array}$ & Japan & $\begin{array}{l}\text { Edoxaban } 5,15,30,60 \mathrm{mg} \text { once daily } \\
\text { versus placebo oral tablet once daily } \\
\text { for II-14 days }\end{array}$ & 523 \\
\hline $\begin{array}{l}\text { Phase III/STARS E-3 } \\
(\text { NCTOI I } 81 \text { I 02) })^{71}\end{array}$ & $\begin{array}{l}\text { Randomized, parallel-group, } \\
\text { double-blind, double-dummy, } \\
\text { enoxaparin-controlled, } \\
\text { noninferiority, multicenter }\end{array}$ & Japan, Taiwan & $\begin{array}{l}\text { Edoxaban } 30 \mathrm{mg} \text { once daily versus } \\
\text { enoxaparin } 20 \mathrm{mg} \text { twice daily for } \\
\text { II-14 days }\end{array}$ & 716 \\
\hline \multicolumn{5}{|l|}{ HFS } \\
\hline $\begin{array}{l}\text { Phase III/STARS J-4 } \\
(\text { NCTOII8II4I) } 72\end{array}$ & $\begin{array}{l}\text { Randomized, open-label, } \\
\text { enoxaparin-controlled, } \\
\text { multicenter }\end{array}$ & Japan & $\begin{array}{l}\text { Edoxaban } 30 \mathrm{mg} \text { once daily versus } \\
\text { enoxaparin } 20 \mathrm{mg} \text { twice daily for } \\
\text { II-I4 days }\end{array}$ & 92 \\
\hline
\end{tabular}

Abbreviations: THR, total hip replacement; TKR, total knee replacement; HFS; hip fracture surgery.

from 53 sites, including the US, Canada, Russia, Ukraine, Denmark, Latvia, and UK. More than $75 \%$ of patients were recruited from Russia and Ukraine. The final distribution among the treatment groups was 170, 151, 158, 151, and 144 patients in the edoxaban $15 \mathrm{mg}, 30 \mathrm{mg}, 60 \mathrm{mg}, 90 \mathrm{mg}$, and dalteparin groups, respectively. Patients who developed symptoms or signs suggestive of deep vein thrombosis prior to planned venography underwent objective testing using either ultrasonography or venography. Patients who developed symptoms or signs suggestive of pulmonary embolism underwent objective testing with computed tomographic pulmonary angiography, ventilation-perfusion lung scanning, or direct pulmonary angiography. Total deep vein thrombosis was defined as the composite of both proximal and distal deep vein thrombosis detected by venography and symptomatic deep vein thrombosis or pulmonary embolism documented by objective testing. Major deep vein thrombosis was defined as the presence of one or more of symptomatic or asymptomatic proximal deep vein thrombosis, symptomatic nonfatal deep vein thrombosis, or death from any cause. Proximal deep vein thrombosis was defined as thrombosis involving the popliteal or more proximal veins. The incidence of total deep vein thrombosis was $28.2 \%, 21.2 \%, 15.2 \%, 10.6 \%$, and $43.8 \%$ in the edoxaban $15 \mathrm{mg}, 30 \mathrm{mg}, 60 \mathrm{mg}, 90 \mathrm{mg}$, and dalteparin groups, respectively (Table 2). The incidence of major deep vein thrombosis was $6.5 \%, 3.3 \%, 1.9 \%, 1.3 \%$, and $13.9 \%$ in the edoxaban $15 \mathrm{mg}, 30 \mathrm{mg}, 60 \mathrm{mg}, 90 \mathrm{mg}$, and dalteparin groups, respectively. The incidence of any proximal deep vein thrombosis was $6.5 \%, 3.3 \%, 1.3 \%, 1.3 \%$, and $13.9 \%$ in the edoxaban $15 \mathrm{mg}, 30 \mathrm{mg}, 60 \mathrm{mg}, 90 \mathrm{mg}$, and dalteparin groups, respectively. There was a statistically significant lower incidence of total deep vein thrombosis in each of the edoxaban dose groups compared with the dalteparin group. There was also a statistically significant dose-response for efficacy across the edoxaban dose groups for efficacy of both total deep vein thrombosis and major deep vein thrombosis. The incidence of the composite of major and clinically relevant nonmajor bleeding was $1.6 \%, 1.8 \%, 2.2 \%$, $2.3 \%$, and $0 \%$ in the edoxaban $15 \mathrm{mg}, 30 \mathrm{mg}, 60 \mathrm{mg}, 90 \mathrm{mg}$, and dalteparin groups, respectively, and 95\% confidence intervals that broadly overlapped (Table 3 ). The incidence of all bleeding was $2.1 \%, 1.8 \%, 4.9 \%, 4.0 \%$, and $0.6 \%$ in 
Table 2 Incidences of total venous thromboembolism in Phase Ilb and III studies of edoxaban for the prevention of venous thromboembolism after major orthopedic surgery

\begin{tabular}{|c|c|c|c|c|c|c|c|c|}
\hline \multirow{2}{*}{$\begin{array}{l}\text { Indication } \\
\text { phase/trial }\end{array}$} & \multicolumn{5}{|l|}{ Edoxaban $^{a}$} & \multirow[t]{2}{*}{ Dalteparin ${ }^{b}$} & \multirow[t]{2}{*}{ Enoxaparin ${ }^{c}$} & \multirow[t]{2}{*}{ Placebo } \\
\hline & $5 \mathrm{mg}$ & $15 \mathrm{mg}$ & $30 \mathrm{mg}$ & $60 \mathrm{mg}$ & $90 \mathrm{mg}$ & & & \\
\hline \multicolumn{9}{|l|}{ THR } \\
\hline $\begin{array}{l}\text { Phase llb/no name }{ }^{67} \\
n / N(\%)\end{array}$ & - & $48 / 170(28.2)$ & $32 / I 5 \mid(2 \mid .2)$ & $24 / 158(15.2)$ & $16 / 15 \mid(10.6)$ & $63 / 144$ (43.8) & - & - \\
\hline $95 \% \mathrm{Cl}$ & & $21.6-35.6$ & 15.0-28.6 & $10.0-2 \mid .8$ & $6.2-16.6$ & $35.5-52.3$ & & \\
\hline \multicolumn{9}{|l|}{ dalteparin } \\
\hline $\begin{array}{l}\text { Phase Ilb/STARS J-2 }{ }^{69} \\
\mathrm{n} / \mathrm{N}(\%)\end{array}$ & - & $3 / 78$ (3.8) & $2 / 72(2.8)$ & - & - & - & $3 / 74(4.1)$ & - \\
\hline Phase III/STARS J-50 & - & - & 6/255 (2.4) & - & - & - & $17 / 248(6.9)$ & - \\
\hline $\mathrm{n} / \mathrm{N}(\%)$ & & & $1.1-5.0$ & & & & $4.3-10.7$ & \\
\hline $95 \% \mathrm{Cl}$ & & & $<0.00 \mathrm{I}^{\mathrm{d}}$ & & & & & \\
\hline$P$ value versus & & & $0.0157^{e}$ & & & & & \\
\hline \multicolumn{9}{|l|}{ enoxaparin } \\
\hline \multicolumn{9}{|l|}{ TKR } \\
\hline $\begin{array}{l}\text { Phase Ilb/STARS J- }\left.\right|^{68} \\
\mathrm{n} / \mathrm{N}(\%)\end{array}$ & $26 / 88(29.5)$ & $24 / 92(26.1)$ & II/88 (I2.5) & $8 / 88(9.1)$ & - & - & - & $43 / 89(48.3)$ \\
\hline $95 \% \mathrm{Cl}$ & $20.0-39.1$ & $17.1-35.1$ & $5.6-19.4$ & $3.1-15.1$ & & & & $37.9-58.7$ \\
\hline $\begin{array}{l}P \text { value versus } \\
\text { placebo }\end{array}$ & 0.01 & 0.002 & $<0.001$ & $<0.001$ & & & & \\
\hline $\begin{array}{l}\text { Phase III/STARS E-371 } \\
n / N(\%)\end{array}$ & - & - & $22 / 299(7.4)$ & - & - & - & $4 I / 295(13.9)$ & - \\
\hline$P$ value versus & & & $<0.00 \mathrm{I}^{\mathrm{d}}$ & & & & & \\
\hline enoxaparin & & & $0.010^{\mathrm{e}}$ & & & & & \\
\hline \multicolumn{9}{|l|}{ HFS } \\
\hline Phase III/STARS J-472 & - & - & $3 / 46(6.5)$ & - & - & - & I/27 (3.7) & - \\
\hline $\mathrm{n} / \mathrm{N}(\%)$ & & & $2.2-17.5$ & & & & $0.7-18.3$ & \\
\hline $95 \% \mathrm{Cl}$ & & & & & & & & \\
\hline
\end{tabular}

Notes: ${ }^{\mathrm{a}}$ Doses of edoxaban were given orally once daily; ${ }^{\mathrm{b}}$ Regimen of subcutaneous dalteparin involved an initial dose of $2500 \mathrm{IU}$ followed by $5000 \mathrm{IU}$ once daily thereafter; 'Subcutaneous enoxaparin $2000 \mathrm{IU}$ equivalent to $20 \mathrm{mg}$ was administered twice daily; ' Noninferiority, FM test (significance level, one-sided $P<0.025$ ); ${ }^{\text {eS }}$ uperiority, FM test (significance level, two-sided $P<0.05$ ).

Abbreviations: THR, total hip replacement; TKR, total knee replacement; HFS, hip fracture surgery; $\mathrm{Cl}$, confidence interval.

the edoxaban $15 \mathrm{mg}, 30 \mathrm{mg}, 60 \mathrm{mg}, 90 \mathrm{mg}$, and dalteparin groups, respectively. The incidence of bleeding outcome events was low and similar across the groups. The point estimates for bleeding outcomes were higher in the edoxaban groups than for dalteparin, but statistically significant differences were not detected. An edoxaban dose-response relationship for bleeding outcomes was not identified. This study showed effectiveness of edoxaban administered orally once daily for preventing deep vein thrombosis after total hip replacement.

\section{Phase Ilb studies for preventing venous thromboembolism after total knee/hip replacement}

A dose-ranging parallel-group, double-blind, placebocontrolled, multicenter Phase IIb study (STARS J-1, NCT01203072, http:/www.clinicaltrials.gov) compared edoxaban with placebo for the prevention of deep vein thrombosis in patients undergoing elective total knee replacement in Japan (Table 1). ${ }^{68}$ Patients were randomized to receive one of four doses $(5,15,30 \mathrm{or} 60 \mathrm{mg})$ of edoxaban or placebo orally once daily for 11-14 days. Treatment was started 6-24 hours after surgery. Mechanical thromboprophylaxis, including intermittent pneumatic compression or a venous foot pump, was permitted at the investigator's discretion. The primary efficacy endpoint was the incidence of total deep vein thrombosis, including distal deep vein thrombosis by standardized mandatory bilateral ascending venography, symptomatic pulmonary embolism confirmed by pulmonary scintigraphy, pulmonary arteriography, computed tomography, or symptomatic deep vein thrombosis confirmed before venography. Venography was performed within 24 hours after the end of the study treatment, or within 96 hours if it could not be performed within 24 hours for any reason. The primary safety endpoint was the incidence of major and clinically relevant nonmajor bleeding. A total of 
Table 3 Incidence of composite of major and clinically relevant nonmajor bleeding in Phase Ilb and III studies of edoxaban for the prevention of venous thromboembolism after major orthopedic surgery

\begin{tabular}{|c|c|c|c|c|c|c|c|c|}
\hline \multirow{2}{*}{$\begin{array}{l}\text { Indication } \\
\text { phase/trial }\end{array}$} & \multicolumn{5}{|l|}{ Edoxaban $^{a}$} & \multirow[t]{2}{*}{ Dalteparin ${ }^{b}$} & \multirow[t]{2}{*}{ Enoxaparin ${ }^{c}$} & \multirow[t]{2}{*}{ Placebo } \\
\hline & $5 \mathrm{mg}$ & $15 \mathrm{mg}$ & $30 \mathrm{mg}$ & $60 \mathrm{mg}$ & $90 \mathrm{mg}$ & & & \\
\hline \multicolumn{9}{|l|}{ THR } \\
\hline $\begin{array}{l}\text { Phase llb/No name }{ }^{67} \\
n / N(\%)\end{array}$ & - & $3 / 192(1.6)$ & $3 / 170(1.8)$ & $4 / 185(2.2)$ & $4 / 177(2.3)$ & $0 / 172(0.0)$ & - & - \\
\hline $95 \% \mathrm{Cl}$ & & $0.3-4.5$ & $0.4-5.1$ & $0.6-5.4$ & $0.6-5.7$ & $0.0-2.1$ & & \\
\hline $\begin{array}{l}\text { Phase Ilb/STARS J-269 } \\
\mathrm{n} / \mathrm{N}(\%)\end{array}$ & - & $2 / 89(2.2)$ & I/85 (1.2) & - & - & - & $2 / 87(2.3)$ & - \\
\hline $\begin{array}{l}\text { Phase III/STARS J-570 } \\
\mathrm{n} / \mathrm{N}(\%)\end{array}$ & - & - & $8 / 303(2.6)$ & - & - & - & $\mathrm{I}|/ 30|(3.7)$ & - \\
\hline $\begin{array}{l}P \text { value versus } \\
\text { enoxaparin } \\
\text { TKR }\end{array}$ & & & 0.475 & & & & & \\
\hline $\begin{array}{l}\text { Phase Ilb/STARS J-I }\left.\right|^{68} \\
\mathrm{n} / \mathrm{N}(\%)\end{array}$ & $2 / 103(1.9)$ & $4 / 106(3.8)$ & 4/I03 (3.9) & $5 / 106(4.7)$ & - & - & - & $4 / 102(3.9)$ \\
\hline $\begin{array}{l}P \text { value versus } \\
\text { placebo }\end{array}$ & 0.445 & 1.000 & 1.000 & 1.000 & & & & \\
\hline $\begin{array}{l}\text { Phase III/STARS E-371 } \\
\mathrm{n} / \mathrm{N}(\%)\end{array}$ & - & - & $22 / 354(6.2)$ & - & - & - & 13/349 (3.7) & - \\
\hline $\begin{array}{l}P \text { value versus } \\
\text { enoxaparin } \\
\text { HFS }\end{array}$ & & & 0.129 & & & & & \\
\hline $\begin{array}{l}\text { Phase III/STARS J-4 } 4^{72} \\
\mathrm{n} / \mathrm{N}(\%)\end{array}$ & - & - & $2 / 59(3.4)$ & - & - & - & $2 / 29(6.9)$ & - \\
\hline $95 \% \mathrm{Cl}$ & & & $0.9-11.5$ & & & & $1.9-22.0$ & \\
\hline
\end{tabular}

Notes: a Doses of edoxaban were given orally once daily; ${ }^{\mathrm{b}}$ Regimen of subcutaneous dalteparin involved an initial dose of $2500 \mathrm{IU}$ followed by $5000 \mathrm{IU}$ once daily thereafter; 'Subcutaneous enoxaparin $2000 \mathrm{IU}$, equivalent to $20 \mathrm{mg}$ was administered.

Abbreviations: THR, total hip replacement; TKR, total knee replacement; HFS, hip fracture surgery; $\mathrm{Cl}$, confidence interval.

523 patients were enrolled. Of these, 520 patients received at least one dose of the study treatment and 492 patients completed the study. The final distribution among the treatment groups was $88,92,88,88$, and 89 patients in the edoxaban $5 \mathrm{mg}, 15 \mathrm{mg}, 30 \mathrm{mg}, 60 \mathrm{mg}$, and placebo groups, respectively. The incidence of the primary efficacy endpoint was $29.5 \%, 26.1 \%, 12.5 \%, 9.1 \%$, and $48.3 \%$ in the edoxaban $5 \mathrm{mg}, 15 \mathrm{mg}, 30 \mathrm{mg}, 60 \mathrm{mg}$, and placebo groups, respectively (Table 2). Symptomatic deep vein thrombosis was detected in one patient in the edoxaban $5 \mathrm{mg}$ group, although there were no deep vein thrombosis-related deaths or symptomatic pulmonary embolism. Proximal deep vein thrombosis occurred in one patient each in the $30 \mathrm{mg}$ and $60 \mathrm{mg}$ groups compared with four patients in the placebo group. With regard to mechanical thromboprophylaxis, $21 \%-28 \%$ of patients received intermittent pneumatic compression and $58 \%-60 \%$ of patients received a venous foot pump. For the total study cohort, deep vein thrombosis was observed in $25.0 \%$ of users versus $25.6 \%$ of nonusers. The incidence of deep vein thrombosis in the placebo group was $47.0 \%$ versus $52.2 \%$ for users versus nonusers, respectively. The incidence of deep vein thrombosis was similar for users and nonusers of intermittent pneumatic compression or a venous foot pump. The incidence of thromboembolic events was inversely related to edoxaban dose. Paired comparison demonstrated no significant differences in the incidence of thromboembolic events between the $5 \mathrm{mg}$ and $15 \mathrm{mg}$ groups or between the $30 \mathrm{mg}$ and $60 \mathrm{mg}$ groups, but significant differences were shown between the $5 \mathrm{mg}$ or $15 \mathrm{mg}$ groups versus the $30 \mathrm{mg}$ or $60 \mathrm{mg}$ groups. The incidence of composite of major bleeding and clinically relevant nonmajor bleeding was $1.9 \%, 3.8 \%$, $3.9 \%, 4.7 \%$, and $3.9 \%$ in the edoxaban $5 \mathrm{mg}, 15 \mathrm{mg}, 30 \mathrm{mg}$, $60 \mathrm{mg}$, and placebo groups, respectively (Table 3). There was one occurrence of major bleeding in the edoxaban $60 \mathrm{mg}$ group, although there were no occurrences of major bleeding in other groups. There was no relationship between the incidence of composite of major and clinically relevant bleeding and edoxaban dosage. There was no difference between any of the edoxaban groups or the placebo group in the composite endpoint of bleeding. The incidence of all treatmentrelated bleeding events, including major, clinically relevant nonmajor, or minor bleeding, was 5.8\%, 10.4\%, 10.7\%, $17.0 \%$, and $17.0 \%$ in the edoxaban $5 \mathrm{mg}, 15 \mathrm{mg}, 30 \mathrm{mg}$, $60 \mathrm{mg}$, and placebo groups, respectively. The incidence 
increased significantly with increasing edoxaban dose and was significantly higher in the edoxaban $60 \mathrm{mg}$ than in the placebo group. The STARS J-1 trial demonstrated that edoxaban administered orally once daily reduced postoperative deep vein thrombosis in patients undergoing elective total knee replacement in a dose-dependent manner, with no associated increase in major or clinically relevant nonmajor bleeding across the dose range relative to placebo, although all bleeding events increased with dose.

The efficacy, safety, and appropriate dosage regimen of edoxaban for prevention of deep vein thrombosis was evaluated in a randomized, parallel-group, double-blind, open-label, enoxaparin-controlled, multidose, multicenter Phase IIb study (STARS J-2, NCT01203098, http://www. clinicaltrials.gov) in 264 patients undergoing elective unilateral total hip replacement in Japan and Taiwan (Table 1). ${ }^{69}$ Double-blind edoxaban $15 \mathrm{mg}$ or $30 \mathrm{mg}$ once daily or open-label subcutaneous enoxaparin $20 \mathrm{mg}$ twice daily was administered for 11-14 days. Edoxaban was started within 6-24 hours and enoxaparin was started within 24-36 hours of surgery. Bilateral venography was performed at the end of the study and centrally adjudicated. The incidence of thromboembolic events was $3.8 \%, 2.8 \%$, and $4.1 \%$ in the edoxaban $15 \mathrm{mg}$, edoxaban $30 \mathrm{mg}$, and enoxaparin groups, respectively (Table 2). Thromboembolic events were all asymptomatic distal deep vein thrombosis. The incidence of major and clinically relevant nonmajor bleeding was $2.2 \%$, $1.2 \%, 2.3 \%$ in the edoxaban $15 \mathrm{mg}$, edoxaban $30 \mathrm{mg}$, and enoxaparin groups, respectively (Table 3 ). There was one major bleeding event in the edoxaban $30 \mathrm{mg}$ group classified as clinically overt bleeding accompanied by a decrease in hemoglobin of $>2 \mathrm{~g} / \mathrm{dL}$. The incidence of adverse drug reactions was $18.0 \%, 25.9 \%, 52.9 \%$ in the edoxaban $15 \mathrm{mg}$, edoxaban $30 \mathrm{mg}$, and enoxaparin groups, respectively. This trial demonstrated that oral administration of edoxaban $15 \mathrm{mg}$ and $30 \mathrm{mg}$ provided efficacy potentially similar to that of enoxaparin for the prevention of thromboembolic events in patients undergoing total hip replacement. The incidence of major and clinically relevant nonmajor bleeding was comparable with that of enoxaparin.

\section{Phase III study in elective total hip replacement}

In the Phase III STARS J-5 trial (NCT01181167 http://www. clinicaltrials.gov), edoxaban showed efficacy superior to that of enoxaparin in the prevention of deep vein thrombosis events in 610 patients following total hip replacement (Table 1). ${ }^{70}$ STARS J-5 was a randomized, parallel-group, double-blind, double-dummy, enoxaparin-controlled, noninferiority, multicenter study in Japan. Patients were randomized to receive oral edoxaban $30 \mathrm{mg}$ once daily or subcutaneous enoxaparin $2000 \mathrm{IU}$ (equivalent to $20 \mathrm{mg}$ ), twice daily for 11-14 days. Edoxaban was initiated 6-24 hours after surgery, and enoxaparin was initiated 24-36 hours after surgery, which is the Japanese standard of care. The primary efficacy endpoint was the composite of symptomatic and asymptomatic deep vein thrombosis and pulmonary embolism. The primary safety endpoint was the incidence of major bleeding and clinically relevant nonmajor bleeding events. The incidence of any deep vein thrombosis was $2.4 \%$ in the edoxaban group and $6.9 \%$ in the enoxaparin group (relative risk reduction $65.7 \%$; absolute risk difference $-4.5 \%, 95 \%$ confidence interval $-8.6 \%$ to $-0.9 \% ; P<0.001$ for noninferiority; $P=0.0157$ for superiority, Table 2 ). The deep vein thromboses were all asymptomatic. The incidence of proximal deep vein thrombosis was $0.4 \%$ in the edoxaban group and $0.8 \%$ in the enoxaparin group. The incidence of distal deep vein thrombosis was $2.4 \%$ in the edoxaban group and $6.5 \%$ in the enoxaparin group. No symptomatic deep vein thrombosis or pulmonary embolism was observed in either treatment group. The incidence of major and clinically relevant nonmajor bleeding events was $2.6 \%$ in the edoxaban group and $3.7 \%$ in the enoxaparin group $(P=0.475$, Table 3$)$. Major bleeding occurred in $0.7 \%$ of the edoxaban group and $2.0 \%$ of the enoxaparin group. The rate of elevated serum aminotransferase levels of more than three times the upper limit of normal was $2.6 \%$ with edoxaban and $10 \%$ with enoxaparin. The STARS J-5 trial demonstrated that oral edoxaban $30 \mathrm{mg}$ once daily had efficacy superior to that of enoxaparin $20 \mathrm{mg}$ twice daily for the prevention of thromboembolic events following total hip replacement and was associated with a similar incidence of major and clinically relevant nonmajor bleeding events.

\section{Phase III study in elective total knee replacement}

STARS E-3 (NCT NCT01181102) was a randomized, parallel-group, double-blind, double-dummy, enoxaparincontrolled, noninferiority, multicenter Phase III study of thromboprophylaxis in 716 Japanese patients undergoing total knee replacement (Table 1). ${ }^{71}$ Patients were randomized to receive oral edoxaban or subcutaneous enoxaparin. The treatment regimen and primary efficacy outcome were the same as those in the Phase III STARS J-5 trial for elective total hip replacement. The incidence of any deep vein thrombosis was $7.4 \%$ in the edoxaban group and $13.9 \%$ in the 
enoxaparin group (relative risk reduction 46.8\%; $P<0.001$ for noninferiority; $P=0.010$ for superiority, Table 2 ). No pulmonary embolism was observed in either treatment group. The incidence of major and clinically relevant nonmajor bleeding events was $6.2 \%$ in the edoxaban group and $3.7 \%$ in the enoxaparin group $(P=0.129$, Table 3$)$. The rate of elevated serum aminotransferase levels of more than three times the upper limit of normal was $1.4 \%$ with edoxaban and $8.0 \%$ with enoxaparin. The STARS E-3 trial demonstrated that oral edoxaban $30 \mathrm{mg}$ once daily had efficacy superior to that of subcutaneous enoxaparin $20 \mathrm{mg}$ twice daily in the prevention of thromboembolic events following total knee replacement.

\section{Phase III study in hip fracture surgery}

The efficacy of edoxaban in the treatment of deep vein thrombosis in 92 patients undergoing hip fracture (femoral neck, trochanteric, and subtrochanteric) surgery has been evaluated in the randomized, open-label, enoxaparin-controlled, multicenter Phase III STARS J-4 trial (NCT01181141) in Japan. ${ }^{72}$ Patients were randomized in a 2:1 ratio to an edoxaban group or an enoxaparin group (Table 1). The treatment regimen was the same as that of the other Phase III studies (STARS J-5 for elective total hip replacement and STARS E-3 for elective total knee replacement). Venography of both legs was conducted within 24 hours of the last dose of the study medication. Seventy-six of 92 patients enrolled completed the study. Baseline characteristics were similar between the treatment groups, although creatinine clearance was lower in the edoxaban group than in the enoxaparin group. The incidence of thromboembolic events was $6.5 \%$ in the edoxaban group and $3.7 \%$ in the enoxaparin group (Table 2). All thromboembolic events were asymptomatic distal deep vein thrombosis. The incidence of major and clinically relevant nonmajor bleeding was $3.4 \%$ in the edoxaban group and 6.9\% in the enoxaparin group (Table 3 ). There was one patient with major bleeding in each group. The incidence of adverse events was similar between the treatment groups. The STARS J-4 trial demonstrated that oral edoxaban $30 \mathrm{mg}$ once daily had similar safety and efficacy to that of subcutaneous enoxaparin for the prevention of deep vein thrombosis in patients undergoing hip fracture surgery.

\section{Pooled analysis of phase III studies}

The results of a pooled analysis of Phase III studies for total hip replacement (STARS J-5 ${ }^{29}$ ) and total knee replacement
(STARS E- $3^{30}$ ) comprising a total of 1326 Japanese and Taiwanese patients were presented at the 53rd Annual Meeting of the American Society of Hematology in December $2011 .^{73}$ The objective of this pooled analysis was to investigate the effects of edoxaban on deep vein thrombosis and bleeding in key patient subgroups. Patients were randomized to receive oral edoxaban $30 \mathrm{mg}$ once daily or subcutaneous enoxaparin $2000 \mathrm{IU}$ (equivalent to $20 \mathrm{mg}$ ) twice daily for 11-14 days. Edoxaban was initiated 6-24 hours and enoxaparin 24-36 hours postoperatively, which is the standard of care in Japan. The primary efficacy outcome was the composite of symptomatic and asymptomatic deep vein thrombosis and pulmonary embolism. The principal safety outcome was the incidence of major and clinically relevant nonmajor bleeding. A total of 1307 patients received at least one dose of edoxaban or enoxaparin. Over $70 \%$ of patients received physiotherapy, including intermittent pneumatic compression and/or elastic stockings. Overall, edoxaban significantly reduced the incidence of the composite of symptomatic and asymptomatic deep vein thrombosis and pulmonary embolism compared with enoxaparin $(5.1 \%$ versus $10.7 \%, P<0.001)$. Subgroup analysis showed that edoxaban numerically reduced the incidence of the composite efficacy endpoint regardless of age or body weight. The effect was statistically significant in patients $<75$ years of age and in those weighing $<70 \mathrm{~kg}$. Edoxaban was also significantly more effective than enoxaparin in the presence or absence of concomitant physiotherapy. The incidence of major and clinically relevant nonmajor bleeding events was $4.6 \%$ versus $3.7 \%$ in the edoxaban and enoxaparin groups, respectively $(P=0.427)$. Subgroup analysis of major and clinically relevant nonmajor bleeding indicated no significant difference between edoxaban and enoxaparin in any of the patient subgroups evaluated, based on age, weight, or creatinine clearance. Therefore, edoxaban $30 \mathrm{mg}$ once daily is superior to enoxaparin $20 \mathrm{mg}$ twice daily in the prevention of deep vein thrombosis events following total hip replacement and total knee replacement without a statistically significant increase in bleeding in important patient subgroups likely to receive this treatment.

\section{Discussion}

Clinical trials suggest that edoxaban is at least as effective as enoxaparin and has a risk of major bleeding similar to that of enoxaparin for the prevention of deep vein thrombosis in patients undergoing major orthopedic surgery. Factor Xa inhibition has emerged as an attractive therapeutic target for reducing the risk of deep vein thrombosis. New oral factor 
Xa inhibitors are an emerging class of oral anticoagulants with potential benefits over warfarin. Edoxaban is a novel direct factor $\mathrm{Xa}$ inhibitor that has undergone Phase III clinical trials in deep vein thrombosis prophylaxis after major orthopedic surgery. ${ }^{70-72}$ Edoxaban is rapidly absorbed, with a time to peak plasma concentration of 1-2 hours and a short half-life of 5.8-10.7 hours. ${ }^{62}$ Edoxaban inhibits factor Xa activity directly and selectively. ${ }^{56,57}$ Edoxaban has strong antithrombotic properties as a result of factor Xa inhibition. ${ }^{56,57,60,61}$ Coagulation monitoring is not required for edoxaban because of its predictable linear pharmacokinetic and pharmacodynamic profile, lack of an effect of food, and low plasma protein binding. ${ }^{62,63}$ In Phase II and III clinical trials, oral administration of edoxaban showed efficacy superior to that of subcutaneously administered dalteparin or enoxaparin in the prevention of thromboembolic events, with similar safety following major orthopedic surgery.

Edoxaban has shown promising results for preventing deep vein thrombosis after major orthopedic surgery. Edoxaban is approved for the prevention of deep vein thrombosis in patients undergoing major orthopedic surgery by a government agency only in Japan at present. Edoxaban has the potential to become a first choice drug in preventing deep vein thrombosis after major orthopedic surgery. In the Phase II and III clinical studies, the efficacy and safety of edoxaban were compared with that of the low molecular weight heparins, dalteparin or enoxaparin. ${ }^{67,69-72}$ However, the dose should be adjusted in patients with renal impairment, low body weight, and/or older age. ${ }^{74}$ In Japan, edoxaban is contraindicated in patients whose creatinine clearance is $<30 \mathrm{~mL} /$ minute. ${ }^{74}$ Subgroup analysis of pooled data from clinical trials in patients undergoing major orthopedic surgery in Japan and Taiwan revealed a higher bleeding risk in an oral edoxaban $30 \mathrm{mg}$ once daily subgroup with moderate renal impairment (creatinine clearance 30-50 $\mathrm{mL} /$ minute), body weight $<50 \mathrm{~kg}$, and/or age $\geq 75$ years, for whom a daily dose of $15 \mathrm{mg}$ is recommended. ${ }^{74}$ Furthermore, P-glycoprotein inhibitors, such as quinidine sulfate, verapamil hydrochloride, amiodarone hydrochloride, erythromycin, and itraconazole, are expected to increase the bioavailability of edoxaban by inhibition of P-glycoprotein in the intestine. Coadministration of these drugs could increase plasma levels of edoxaban, leading to an increased bleeding risk. ${ }^{56,74,75}$ Therefore, a reduced dosage should be considered when patients are receiving concomitant administration of these drugs. ${ }^{74}$

The incidence of total deep vein thrombosis in the multinational Phase IIb study of total hip replacement ${ }^{67}$ was higher than that in the Phase IIb trial in Japan ${ }^{69}$ and Taiwan and in the Phase III trial in Japan. ${ }^{70}$ The incidence might be affected by ethnicity, body mass index, or body weight. The great majority (98\%) of patients in the multinational trial were Caucasian. The incidence of deep vein thrombosis in the general population is lower among Japanese and Taiwanese than in Caucasians. ${ }^{76,77}$ Average body mass index in the multinational Phase IIb trial was approximately $28 \mathrm{~kg} / \mathrm{m}^{2}$, while average body weight in the Phase III trial in Japan was $57.4 \mathrm{~kg}$. It is presumed that patients in the multinational trial were heavier than those in the Japanese trial. Body mass index has a stronger association with risk of deep vein thrombosis not only in the general population ${ }^{78,79}$ but also in patients after total hip arthroplasty. ${ }^{80,81}$

Mechanical thromboprophylaxis with a venous foot pump or intermittent pneumatic compression is recommended with/without anticoagulant thromboprophylaxis for patients undergoing major orthopedic surgery according to guidelines from the American College of Chest Physicians, National Institute for Health and Clinical Excellence, and American Association of Orthopedic Surgeons. ${ }^{1,4,42}$ Mechanical thromboprophylaxis with intermittent pneumatic compression has been used for almost 25 years. ${ }^{82}$ Mechanical prophylaxis with intermittent pneumatic compression in combination with other nonpharmacologic modalities, such as regional anesthesia and rapid mobilization, with or without aspirin, is also reportedly as being effective as thromboprophylaxis for deep vein thrombosis. ${ }^{82-88}$ Among the reviewed articles, only a multidose Phase IIb report for patients undergoing total knee replacement ${ }^{68}$ has described the results of mechanical prophylaxis. The incidence of deep vein thrombosis was similar for users and nonusers of intermittent pneumatic compression or a venous foot pump in the trial.

\section{Limitations}

Some limitations of past clinical studies of edoxaban for deep vein thrombosis prophylaxis after major orthopedic surgery should be noted. First, the racial and ethnic distribution of the patient populations in these studies was disproportionate. Although the dose-finding Phase IIb trial was multinational, more than $75 \%$ of patients were recruited from Russia and Ukraine, and only about $17 \%$ were recruited from the US, with less than $0.5 \%$ from Western Europe. Patients in the other Phase II and III trials were only recruited from Japan or Taiwan. Second, the scale of all studies was small. The largest one, which was a dose-finding Phase IIb trial for total hip replacement, included only 903 patients, and the patient population in the pooled analysis of Phase III studies was 
only 1326. Third, treatment with enoxaparin $20 \mathrm{mg}$ twice daily was started within 24-36 hours of surgery. This regimen is the standard of care in Japan but is not commonly used in other countries. Consequently, larger multinational trials, in which the protocol of comparator treatment is popular in other regions, are required to confirm the efficacy and safety as well as optimum dose of edoxaban for the prevention of deep vein thrombosis after major orthopedic surgery. There are some reports comparing the efficacy and safety of the indirect factor Xa inhibitor, fondaparinux, with that of enoxaparin for the prevention of deep vein thrombosis after major orthopedic surgery. ${ }^{89-93}$ However, no clinical results for the efficacy and safety of the factor Xa inhibitors has ever been reported. Furthermore, specific antidotes are still being investigated. ${ }^{94}$ It is expected that more information will be reported in the near future.

\section{Disclosure}

The authors report no conflicts of interest in this work.

\section{References}

1. National Institute for Health and Clinical Excellence. Reducing the risk of venous thromboembolism (deep vein thrombosis and pulmonary embolism) in inpatients admitted to hospital. NICE Clinical Guideline No 92:1-519. Available from: http://guidance.nice.org.uk/CG92. Accessed December 16, 2011.

2. Bell WR, Simon TL. Current status of pulmonary thromboembolic disease: pathophysiology, diagnosis, prevention, and treatment. Am Heart J. 1982;103(2):239-262.

3. McRae SJ, Ginsberg JS. Initial treatment of venous thromboembolism. Circulation. 2004;110(9 Suppl 1):I3-I9.

4. Geerts WH, Bergqvist D, Pineo GF, et al. Prevention of venous thromboembolism: American College of Chest Physicians EvidenceBased Clinical Practice Guidelines (8th Edition). Chest. 2008;133 Suppl 6:S381-S453.

5. Weinmann EE, Salzman EW. Deep vein thrombosis. $N$ Engl J Med. 1994;331(24):1630-1641.

6. Khaw FM, Moran CG, Pinder IM, Smith SR. The incidence of fatal pulmonary embolism after knee replacement with no prophylactic anticoagulation. J Bone Joint Surg Br. 1993;75(6):940-941.

7. Kakkar VV, Howe CT, Flanc C, Clarke MB. Natural history of postoperative deep-vein thrombosis. Lancet. 1969;2(7614): 230-232.

8. Moser KM, LeMoine JR. Is embolic risk conditioned by location of deep venous thrombosis? Ann Intern Med. 1981;94(4 Pt 1): 439-444.

9. Lieberman JR, Geerts WH. Prevention of venous thromboembolism after total hip and knee arthroplasty. J Bone Joint Surg Am. 1994;76(8): $1239-1250$.

10. Anderson FA Jr, Wheeler HB, Goldberg RJ, et al. A population-based perspective of the hospital incidence and case-fatality rates of deep vein thrombosis and pulmonary embolism. The Worcester DVT Study. Arch Intern Med. 1991;151(5):933-938.

11. Nordström M, Lindblad B, Bergqvist D, Kjellström T. A prospective study of the incidence of deep-vein thrombosis within a defined urban population. J Intern Med. 1992;232(2):155-160.

12. Heit J, Petterson T, Farmer S, Bailey K, Melton L. Trends in incidence of deep vein thrombosis and pulmonary embolism: a 35-year populationbased study. Blood. 2006;108:430a.
13. Naess IA, Christiansen SC, Romundstad P, Cannegieter SC, Rosendaal FR, Hammerstrøm J. Incidence and mortality of venous thrombosis: a population-based study. J Thromb Haemost. 2007;5(4):692-699.

14. Geerts WH, Pineo GF, Heit JA, et al. Prevention of venous thromboembolism: the Seventh ACCP Conference on Antithrombotic and Thrombolytic Therapy. Chest. 2004;126 Suppl 3:S338-S400.

15. Gallus A, Raman K, Darby T. Venous thrombosis after elective hip replacement - the influence of preventive intermittent calf compression and of surgical technique. Br J Surg. 1983;70(1):17-19.

16. Turpie AG, Levine MN, Hirsh J, et al. A randomized controlled trial of a low-molecular-weight heparin (enoxaparin) to prevent deep-vein thrombosis in patients undergoing elective hip surgery. $N$ Engl $J$ Med. 1986;315(15):925-929.

17. Beisaw NE, Comerota AJ, Groth HE, et al. Dihydroergotamine/heparin in the prevention of deep-vein thrombosis after total hip replacement: A controlled, prospective, randomized multicenter trial. J Bone Joint Surg Am. 1988;70(1):2-10.

18. Haake DA, Berkman SA. Venous thromboembolic disease after hip surgery. Risk factors, prophylaxis, and diagnosis. Clin Orthop Relat Res. 1989;242:212-231.

19. Hull RD, Raskob GE, Gent M, et al. Effectiveness of intermittent pneumatic leg compression for preventing deep vein thrombosis after total hip replacement. JAMA. 1990;263(17):2313-2317.

20. Lassen MR, Borris LC, Christiansen HM, et al. Prevention of thromboembolism in 190 hip arthroplasties. Comparison of LMW heparin and placebo. Acta Orthop Scand. 1991;62(1):33-38.

21. Hoek JA, Nurmohamed MT, Hamelynck KJ, et al. Prevention of deep vein thrombosis following total hip replacement by low molecular weight heparinoid. Thromb Haemost. 1992;67(1):28-32.

22. Freedman KB, Brookenthal KR, Fitzgerald RH Jr, Williams S, Lonner JH. A meta-analysis of thromboembolic prophylaxis following elective total hip arthroplasty. J Bone Joint Surg Am. 2000;82(7):929-938.

23. Stulberg BN, Insall JN, Williams GW, Ghelman B. Deep-vein thrombosis following total knee replacement. An analysis of six hundred and thirtyeight arthroplasties. J Bone Joint Surg Am. 1984;66(2):194-201.

24. Lynch AF, Bourne RB, Rorabeck CH, Rankin RN, Donald A. Deep-vein thrombosis and continuous passive motion after total knee arthroplasty. J Bone Joint Surg Am. 1988;70(1):11-14.

25. Stringer MD, Steadman CA, Hedges AR, Thomas EM, Morley TR, KakkarVV. Deep vein thrombosis after elective knee surgery. An incidence study in 312 patients. J Bone Joint Surg Br. 1989;71(3):492-497.

26. Leclerc JR, Geerts WH, Desjardins L, et al. Prevention of deep vein thrombosis after major knee surgery - a randomized, double-blind trial comparing a low molecular weight heparin fragment (enoxaparin) to placebo. Thromb Haemost. 1992;67(4):417-423.

27. Lotke PA, Palevsky H, Keenan AM, et al. Aspirin and warfarin for thromboembolic disease after total joint arthroplasty. Clin Orthop Relat Res. 1996;324:251-258.

28. Westrich GH, Sculco TP. Prophylaxis against deep venous thrombosis after total knee arthroplasty. Pneumatic planter compression and aspirin compared with aspirin alone. J Bone Joint Surg Am. 1996;78(6): 826-834.

29. Levine MN, Gent M, Hirsh J, et al. Ardeparin (low-molecular-weight heparin) vs graduated compression stockings for the prevention of venous thromboembolism. A randomized trial in patients undergoing knee surgery. Arch Intern Med. 1996;156(8):851-856.

30. Warwick D, Harrison J, Whitehouse S, Mitchelmore A, Thornton M. A randomised comparison of a foot pump and low-molecular-weight heparin in the prevention of deep-vein thrombosis after total knee replacement. J Bone Joint Surg Br. 2002;84(3):344-350.

31. Snook GA, Chrisman OD, Wilson TC. Thromboembolism after surgical treatment of hip fractures. Clin Orthop Relat Res. 1981;155:21-24.

32. Powers PJ, Gent M, Jay RM, et al. A randomized trial of less intense postoperative warfarin or aspirin therapy in the prevention of venous thromboembolism after surgery for fractured hip. Arch Intern Med. 1989;149(4):771-774. 
33. Agnelli G, Cosmi B, Di Filippo P, et al. A randomised, double-blind, placebo-controlled trial of dermatan sulphate for prevention of deep vein thrombosis in hip fracture. Thromb Haemost. 1992;67(2):203-208.

34. Fender D, Harper WM, Thompson JR, Gregg PJ. Mortality and fatal pulmonary embolism after primary total hip replacement. Results from a regional hip register. J Bone Joint Surg Br. 1997;79(6):896-899.

35. Warwick D, Bannister GC, Glew D, et al. Perioperative low-molecularweight heparin. Is it effective and safe? J Bone Joint Surg Br. 1995; 77(5):715-719.

36. Mohr DN, Silverstein MD, Ilstrup DM, Heit JA, Morrey BF. Venous thromboembolism associated with hip and knee arthroplasty: current prophylactic practices and outcomes. Mayo Clin Proc. 1992;67(9): 861-870.

37. Murray DW, Britton AR, Bulstrode CJ. Thromboprophylaxis and death after total hip replacement. J Bone Joint Surg Br. 1996;78(6): 863-870.

38. Colwell CW Jr, Collis DK, Paulson R, et al. Comparison of enoxaparin and warfarin for the prevention of venous thromboembolic disease after total hip arthroplasty. Evaluation during hospitalization and three months after discharge. J Bone Joint Surg Am. 1999;81(7): 932-940.

39. Leclerc JR, Gent M, Hirsh J, Geerts WH, Ginsberg JS. The incidence of symptomatic venous thromboembolism during and after prophylaxis with enoxaparin: a multi-institutional cohort study of patients who underwent hip or knee arthroplasty. Arch Intern Med. 1998;158(8): 873-878.

40. Ansari S, Warwick D, Ackroyd CE, Newman JH. Incidence of fatal pulmonary embolism after 1,390 knee arthroplasties without routine prophylactic anticoagulation, except in high-risk cases. J Arthroplasty. 1997;12(6):599-602.

41. Todd CJ, Freeman CJ, Camilleri-Ferrante C, et al. Differences in mortality after fracture of hip: the East Anglian audit. BMJ. 1995; 310(6984):904-908

42. Haas SB, Barrack RL, Westrich G, Lachiewicz PF. Venous thromboembolic disease after total hip and knee arthroplasty. J Bone Joint Surg Am. 2008;90(12):2764-2780.

43. Eikelboom JW, Karthikeyan G, Fagel N, Hirsh J. American Association of Orthopedic Surgeons and American College of Chest Physicians guidelines for venous thromboembolism prevention in hip and knee arthroplasty differ: what are the implications for clinicians and patients? Chest. 2009;135(2):513-520.

44. Eriksson BI, Quinlan DJ, Eikelboom JW. Novel oral factor Xa and thrombin inhibitors in the management. Ann Rev Med. 2011;62:41-57.

45. Mehta RS. Novel oral anticoagulants for prophylaxis and treatment of venous thromboembolism: part I (factor Xa inhibitors). Expert Rev Hematol. 2010;3(2):227-241.

46. Ansell J, Hirsh J, Hylek E, Jacobson A, Crowther M, Palareti G. Pharmacology and management of the vitamin K antagonists: American College of Chest Physicians Evidence-Based Clinical Practice Guidelines (8th Edition). Chest. 2008;133 Suppl 6:S160-S198.

47. Mavrakanas T, Bounameaux H. The potential role of new oral anticoagulants in the prevention and treatment of thromboembolism. Pharmacol Ther. 2011;130(1):46-58.

48. Hirsh J, Raschke R. Heparin and low-molecular-weight heparin: the Seventh ACCP Conference on Antithrombotic and Thrombolytic Therapy. Chest. 2004;126 Suppl 3:S188-S203.

49. Hirsh J, Bauer KA, Donati MB, Gould M, Samama MM, Weitz JI. Parenteral anticoagulants: American College of Chest Physicians Evidence-Based Clinical Practice Guidelines (8th Edition). Chest. 2008;133 Suppl 6:S141-S159.

50. Van Aken H, Bode C, Darius H, et al. Anticoagulation: the present and future. Clin Appl Thromb Hemost. 2001;7(3):195-204.

51. Connolly SJ, Eikelboom J, O’Donnell M, Pogue J, Yusuf S. Challenges of establishing new antithrombotic therapies in atrial fibrillation. Circulation. 2007;116(4):440-455.

52. Eikelboom JW, Weitz JI. A replacement for warfarin: the search continues. Circulation. 2007;116(2):131-133.
53. Hirsh J, Warkentin TE, Shaughnessy SG, et al. Heparin and low-molecularweight heparin: mechanisms of action, pharmacokinetics, dosing, monitoring, efficacy, and safety. Chest. 2001;119 Suppl 1: S64-S94.

54. Warkentin TE, Levine MN, Hirsh J, et al. Heparin-induced thrombocytopenia in patients treated with low-molecular-weight heparin or unfractionated heparin. $N$ Engl $J$ Med. 1995;332(20): $1330-1335$.

55. Warkentin TE, Roberts RS, Hirsh J, Kelton JG. An improved definition of immune heparin-induced thrombocytopenia in postoperative orthopedic patients. Arch Intern Med. 2003;163(20):2518-2524.

56. Zafar MU, Vorchheimer DA, Gaztanaga J, et al. Antithrombotic effects of factor Xa inhibition with DU-176b: Phase-I study of an oral, direct factor Xa inhibitor using an ex-vivo flow chamber. Thromb Haemost. 2007;98(4):883-888.

57. Furugohri T, Isobe K, Honda Y, et al. DU-176b, a potent and orally active factor Xa inhibitor: in vitro and in vivo pharmacological profiles. J Thromb Haemost. 2008;6(9):1542-1549.

58. Rai R, Sprengeler PA, Elrod KC, Young WB. Perspectives on factor Xa inhibition. Curr Med Chem. 2001;8(2):101-119.

59. Daiichi Sankyo Limited. Daiichi Sankyo launches Lixiana ${ }^{\circledR}$ (edoxaban), a direct oral factor Xa inhibitor, in Japan for the prevention of venous thromboembolism after major orthopedic surgery: first direct oral factor Xa inhibitor available to Japanese patients. Available from: http://www. daiichisankyo.com/news/detail/004123.html. Accessed December 26, 2011.

60. Morishima Y, Furugohri T, Isobe $\mathrm{K}$, et al. In vitro characteristics, anticoagulant effects and in vivo antithrombotic efficacy of a novel, potent and orally active direct factor Xa inhibitor, DU-176b [Abstract]. Blood. 2004;104:1862.

61. Furugohri T, Honda Y, Matsumoto C, et al. Antithrombotic and hemorrhagic effects of DU-176b, a novel, potent and orally active direct factor Xa inhibitor: a wider safety margin compared to heparins and warfarin [Abstract]. Blood. 2004;104:1851

62. Ogata K, Mendell-Harary J, Tachibana M, et al. Clinical safety, tolerability, pharmacokinetics, and pharmacodynamics of the novel factor Xa inhibitor edoxaban in healthy volunteers. J Clin Pharmacol. 2010;50(7):743-753.

63. Mendell J, Tachibana M, Shi M, Kunitada S. Effects of food on the pharmacokinetics of edoxaban, an oral direct factor Xa inhibitor, in healthy volunteers. J Clin Pharmacol. 2011;51(5):687-694.

64. Samama MM, Kunitada S, Oursin A, Depasse F, Heptinstall S. Comparison of a direct factor $\mathrm{Xa}$ inhibitor, edoxaban, with dalteparin and ximelagatran: a randomised controlled trial in healthy elderly adults. Thromb Res. 2010;126(4):e286-e293.

65. Turpie AG. Oral, direct factor Xa inhibitors in development for the prevention and treatment of thromboembolic diseases. Arterioscler Thromb Vasc Biol. 2007;27(6):1238-1247.

66. Hylek EM. DU-176b, an oral, direct factor Xa antagonist. Curr Opin Investig Drugs. 2007;8(9):778-783.

67. Raskob G, Cohen AT, Eriksson BI, et al. Oral direct factor Xa inhibition with edoxaban for thromboprophylaxis after elective total hip replacement. A randomised double-blind dose-response study. Thromb Haemost. 2010;104(3):642-649.

68. Fuji T, Fujita S, Tachibana S, Kawai Y. A dose-ranging study evaluating the oral factor Xa inhibitor edoxaban for the prevention of venous thromboembolism in patients undergoing total knee arthroplasty. J Thromb Haemost. 2010;8(11):2458-2468.

69. Fuji T, Wang C-J, Fujita S, Tachibana S, Kawai Y. Edoxaban in patients undergoing total hip arthroplasty: a phase IIb dose-finding study [Abstract]. Blood. 2009;114:2098.

70. Fuji T, Fujita S, Tachibana S, et al. Efficacy and safety of edoxaban versus enoxaparin for the prevention of venous thromboembolism following total hip arthroplasty: STARS J-V trial [Abstract]. Blood. 2010;116:3320.

71. Fuji T, Wang C-J, Fujita S, et al. Edoxaban versus enoxaparin for thromboprophylaxis after total knee arthroplasty: the STARS E-3 trial [Abstract]. Pathophysiol Haemost Thromb. 2010;37:OC297. 
72. Fujita S, Fuji T, Tachibana S, Nakamura M, Kawai Y. Safety and efficacy of edoxaban in patients undergoing hip fracture surgery [Abstract]. Pathophysiol Haemost Thromb. 2010;37:P366.

73. Fuji T, Fujita S, Tachibana S, Kawai Y. Edoxaban versus enoxaparin for the prevention of venous thromboembolism: pooled analysis of venous thromboembolism and bleeding from STARS E-III and STARS J-V. Abstract presented at the 53rd American Society of Hematology Annual Meeting and Exposition, December 10-13, 2011, San Diego, CA.

74. Tokyo: Daiichi Sankyo Co., Ltd; 2011 Jul. Interview Form (product information booklet) of LIXIANA ${ }^{\circledR}$ Tablets. 2nd ed. (in Japanese).

75. Partida RA, Giugliano RP. Edoxaban: pharmacological principles, preclinical and early-phase clinical testing. Future Cardiol. 2011;7(4): 459-470.

76. Sakuma M, Nakamura M, Yamada N, et al. Venous thromboembolism: deep vein thrombosis with pulmonary embolism, deep vein thrombosis alone, and pulmonary embolism alone. Circ J. 2009;73(2):305-309.

77. Lee CH, Cheng CL, Lin LJ, Tsai LM, Yang YH. Epidemiology and predictors of short-term mortality in symptomatic venous thromboembolism. Circ J. 2011;75(8):1998-2004.

78. Tsai AW, Cushman M, Rosamond WD, Heckbert SR, Polak JF, Folsom AR. Cardiovascular risk factors and venous thromboembolism incidence: the longitudinal investigation of thromboembolism etiology. Arch Intern Med. 2002;162(10):1182-1189.

79. Glynn RJ, Rosner B. Comparison of risk factors for the competing risks of coronary heart disease, stroke, and venous thromboembolism. Am J Epidemiol. 2005;162(10):975-982.

80. White RH, Gettner S, Newman JM, Trauner KB, Romano PS. Predictors of rehospitalization for symptomatic venous thromboembolism after total hip arthroplasty. N Engl J Med. 2000;343(24):1758-1764.

81. Mantilla CB, Horlocker TT, Schroeder DR, Berry DJ, Brown DL. Risk factors for clinically relevant pulmonary embolism and deep venous thrombosis in patients undergoing primary hip or knee arthroplasty. Anesthesiology. 2003;99(3):552-560.

82. Lachiewicz PF, Soileau ES. Multimodal prophylaxis for THA with mechanical compression. Clin Orthop Relat Res. 2006;453:225-230.

83. Woolson ST. Intermittent pneumatic compression prophylaxis for proximal deep venous thrombosis after total hip replacement. J Bone Joint Surg Am. 1996;78(11):1735-1740.

84. Hooker JA, Lachiewicz PF, Kelley SS. Efficacy of prophylaxis against thromboembolism with intermittent pneumatic compression after primary and revision total hip arthroplasty. J Bone Joint Surg Am. 1999;81(5):690-696.
85. Ryan MG, Westrich GH, Potter HG, et al. Effect of mechanical compression on the prevalence of proximal deep venous thrombosis as assessed by magnetic resonance venography. J Bone Joint Surg Am. 2002;84(11):1998-2004.

86. Pitto RP, Hamer H, Heiss-Dunlop W, Kuehle J. Mechanical prophylaxis of deep-vein thrombosis after total hip replacement: a randomised clinical trial. J Bone Joint Surg Br. 2004;86(5):639-642.

87. Dorr LD, Gendelman V, Maheshwari AV, Boutary M, Wan Z, Long WT. Multimodal thromboprophylaxis for total hip and knee arthroplasty based on risk assessment. J Bone Joint Surg Am. 2007;89(12): 2648-2657.

88. Salvati EA, Sharrock NE, Westrich G, Potter HG, Valle AG, Sculco TP. Three decades of clinical, basic, and applied research on thromboembolic disease after THA: rationale and clinical results of a multimodal prophylaxis protocol. Clin Orthop Relat Res. 2007;459:246-254.

89. Eriksson BI, Bauer KA, Lassen MR, Turpie AGG. Fondaparinux compared with enoxaparin for the prevention of venous thromboembolism after hip-fracture surgery. $N$ Engl J Med. 2001;345(18): 1298-1304.

90. Bauer KA, Eriksson BI, Lassen MR, Turpie AGG. Fondaparinux compared with enoxaparin for the prevention of venous thromboembolism after elective major knee surgery. $N$ Engl J Med. 2001;345(18): $1305-1310$

91. Lassen MR, Bauer KA, Eriksson BI, Turpie AGG. Postoperative fondaparinux versus preoperative enoxaparin for prevention of venous thromboembolism in elective hip-replacement surgery: a randomised double-blind comparison. Lancet. 2002;359(9319):1715-1720.

92. Turpie AGG, Bauer KA, Eriksson BI, Lassen MR. Postoperative fondaparinux versus postoperative enoxaparin for prevention of venous thromboembolism after elective hip-replacement surgery: a randomised double-blind trial. Lancet. 2002;359(9319):1721-1726.

93. Turpie AGG, Bauer KA, Eriksson BI, Lassen MR. Superiority of fondaparinux over enoxaparin in preventing venous thromboembolism in major orthopedic surgery using different efficacy end points. Chest. 2004;126(2):501-508.

94. Fukuda T, Honda Y, Kamisato C, Morishima Y, Shibano T. Reversal of anticoagulant effects of edoxaban, an oral, direct factor Xa inhibitor, with haemostatic agents. Thromb Haemost. 2012;107(2):253-259. [Epub ahead of print.]
Orthopedic Research and Reviews

\section{Publish your work in this journal}

Orthopedic Research and Reviews is an international, peer-reviewed, open access journal focusing on the patho-physiology of the musculoskeletal system, trauma, surgery and other corrective interventions to restore mobility and function. Advances in new technologies, materials, techniques and pharmacological agents are particularly welcome. The journal welcomes

\section{Dovepress}

original research, clinical studies, reviews \& evaluations, expert opinion and commentary, case reports and extended reports. The manuscript management system is completely online and includes a very quick and fair peer-review system, which is all easy to use. Visit http://www.dovepress. com/testimonials.php to read real quotes from published authors. 